\title{
UPAYA MENINGKATKAN HASIL BELAJAR IPA DENGAN MENGGUNAKAN PENDEKATAN SAINTIFIK PADAPESERTA DIDIK KELAS V SDS MUHAMMADIYAH PLUS KABUPATEN KAPUAS TAHUN PELAJARAN 2014/2015
}

\author{
Oleh \\ Mira, Agung Riadin
}

\begin{abstract}
ABSTRAK
Penelitian ini bertujuan untuk: (1) meningkatkan aktivitas belajar IPA dengan menggunakan pendekatan saintifik, (2) meningkatan hasil belajar IPA dengan menggunakan pendekatan saintifik. Metode yang digunakan peneliti adalah menggunakan rancangan penelitian Tindakan kelas (PTK) yang berusaha memecahkan atau menjawab permasalahan yang dihadapi pada situasi sekarang. Subjek dalam penelitian ini adalah seluruh peserta didik kelas V SDS Muhammadiyah Plus Kabupaten Kapuas yang terdiri dari 10 orang peserta didik, 5 orang laki-laki dan 5 orang perempuan. Untuk teknik pengumpulan data yang digunakan adalah observasi dan tes. Sedangkan dalam penelitian ini menggunakan analisis nilai rata-rata kelas dan persentase ketuntasan belajar klasikal.

Hasil penelitian ini menunjukan bahwa penerapan pendekatan saintifik dapat meningkatkan hasil belajar IPA peserta didik kelas V SDS Muhammadiyah Plus Kabupaten Kapuas. Hal ini berdasarkan hasil penelitian dengan perolehan nilai dalam kegiatan pembelajaran yang telah dilakukan selama dua siklus, dapat disimpulkan bahwa: Penerapan pendekatan saintifik dapat meningkatkan hasil belajar peserta didik, ini dapat dilihat dari ratarata pra tindakan $=52$ rata-rata siklus $I=71$ dan siklus $I I=83,5$ dengan ketuntasan klasikal $100 \%$.
\end{abstract}

(C) Universitas Muhammadiyah Palangkaraya

\section{Kata Kunci: Hasil belajar, IPA, Pendekatan Saintifik.}

PENDAHULUAN

IPA memiliki potensi besar untuk memainkan peran strategis dalam menyiapkan sumber daya manusia untuk menghadapi era industrialisasi dan globalisasi. Potensi tersebut dapat terwujud jika pendidikan IPA berorientasi pada pengembangan kemampuan berpikir dan berbahasa, penyiapan peserta ddik menghadapi isu sosial dampak penenrapan IPTEK, penanaman nilai-nilai etika dan estetika, kemampuan memecahkan masalah, pengembangan sikap kemandirian, kreatif serta tanggung jawab.

Ilmu Pengetahuan Alam (IPA) merupakan mata pelajaran yang dimaksudkan agar siswa mempunyai pengetahuan, gagasan dan konsepkonsep yang terorganisasi dengan alam sekitar, yang diperoleh dari pengalaman melalui serangkaian proses ilmiah, antara lain penyelidikan, penyusunan dan penyjian gagasan-gagasan. Di dalam Ilmu Pengetahuan alam (IPA) siswa dituntut memahami konsep- 
konsep Ilmu Pengetahuan Alam (IPA), melalui kegiatan-kegiatan dari mengamati sampai menarik kesimpulan, sehingga terbentuk sikap kritis dan ilmiah.

Namun kenyataan di lapangan, ditemukan bahwa pembelajaran IPA masih rendah yang berpengaruh pada pembelajaran dan hasil belajar. Menurut Djohar (Bolger, 2008:1) bahwa : "Secara umum pembelajaran IPA saat ini belum berorientasi pada proses belajar, namun lebih mementingkan pada produk belajar, yakni pada pengetahuan". Interaksi guru dan peserta didik sekedar transfer pengetahuan dari seorang guru terhadap peserta didik.

Berdasarkan hasil observasi pada peserta didik kelas V SDS Muhammadiyah Plus kabupaten Kapuas Tahun Pelajaran 2014/2015 diketahui bahwa proses pembelajaran IPA masih berpusat pada guru. Guru terlihat cenderung lebih aktif daripada peserta didiknya. Hal ini terlihat bahwa gurulah yang lebih dominan berbicara daripada peserta didiknya. Pembelajaran juga cenderung bersifat hafalan dan kurang bermakna. Selain itu, kegiatan praktek sangat jarang sekali dilakukan, pembelajaran juga cenderung dilaksanakan di dalam kelas, tidak pernah belajar langsung di lingkungan terbuka.

Dari segi peserta didik. peserta didik kurang bersemangat dalam belajar. Sebagian besar peserta didik mengantuk dan bahkan ada sebagian peserta didik yang tidak mau menulis dan jika diberikan tugas, ada beberapa orang peserta didik yang tidak mau mengerjakan tugas tersebut. Hal ini berdampak pada hasil belajar IPA peserta didik, dari 10 orang peserta didik, ada $60 \%$ atau 6 orang peserta didik memperoleh nilai kurang dari 60 atau dibawah kriteria ketuntasan minimal (KKM). Sedangkan yang tuntas yaitu hanya $40 \%$ atau 4 orang peserta didik saja.

Berdasarkan permasalahan di atas guru membutuhkan strategi yang tepat dalam melaksanakan kegiatan pembelajaran, dimana strategi ini terdiri dari model, pendekatan dan metode. Penerapan pendekatan yang tepat merupakan salah satu faktor pendukung yang sangat penting dalam membentuk sikap kritis dan ilmiah pada peserta didik sehingga mereka dapat memperoleh hasil belajar yang optimal. Salah satu pendekatan yang bisa diterapkan dalam membentuk sikap kritis dan ilmiah pada peserta didik dalam pembelajaran IPA adalah pendekatan saintifik.

Pendekatan saintifik adalah pendekatan dengan menggunakan metode ilmiah, dimana dalam proses pembelajarannya ada proses $5 \mathrm{M}$ yaitu mengamati, menanya, mengumpulkan informasi, mengolah informasi dan mengkomunikasikan. Dalam kegiatan pembelajaran, proses pembelajarannya selalu berpusat pada peserta didik (student centered). Tujuan pembelajaran dengan pendekatan saintfik yaitu : 1) Untuk meningkatkan kemampuan intelek, khususnya kemampuan berpikir tingkat tinggi siswa. 2) untuk membentuk kemampuan siswa dalam menyelesaikan suatu masalah secara sistematik. 3) 
terciptanya kondisi pembelajaran dimana siswa merasa bahwa belajar itu merupakan suatu kebutuhan, 4) diperolehnya hasil belajar yang tinggi, 5) untuk melatih siswa dalam mengomunikasikan ide-ide, khususnya dalam menulis artikel ilmiah dan 6) untuk mengembangkan karakter siswa. (Daryanto 2014: 54). Berdasarkan penjelasan yang dipaparkan maka peneliti ingin mengkaji secara mendalam mengenai penggunaan pendekatan saintifik dalam pembelajaran IPA, sehingga akan diketahui apakah akan berpengaruh pada hasil belajar peserta didik atau sebaliknya, yaitu melalui Penelitian Tindakan Kelas (PTK) yang berjudul "Meningkatnya Hasil Belajar IPA Dengan Menggunakan Pendekatan Saintifik Pada peserta Didik Kelas V SDS Muhammadiyah Plus Kabupaten Kapuas Tahun Pelajaran 2014/2015.

\section{METODE PENELITIAN}

Jenis penelitian ini menggunakan penelitian tindakan kelas (PTK). Penelitian tindakan kelas (PTK) merupakan suatu jenis penelitian yang dilakukan oleh guru untuk memecahkan masalah pembelajaran di kelasnya. Menurut Reason dan Breadbury (Kunandar, 2012:44) Penelitian tindakan adalah proses partisipatori, demokratis yang berkenaan dengan pengembangan pengetahuan praktis untuk mencapai tujuan-tujuan mulia manusia, berlandaskan pandangan dunia partisipatori yang muncul pada monentum histori sekarang ini. Ia berusaha memadukan tindakan dengan refleksi, teori dengan praktik, dengan menyertakan pihak-pihak lain, usaha menemukan solusi praktis terhadap persoalan-persoalan yang menyesakkan, dan lebih umum lagi demi pengembangan individu-individu bersama komunitasnya.

Kehadiran peneliti sangat diperlukan dalam setiap kegiatan di tempat penelitian karena peneliti berperan sebagai perencana, pelakanaan tindakan, pengamat, reflektor dan sebagai pelapor hasil penelitian. Sebagai subjek pemberi tindakan, peneliti bertindak sebagai pengajar atau guru model yang bertugas membuat rancangan pelaksanaan pembelajaran (RPP) sekaligus menyampaikan bahan ajar selama proses pembelajaran. Di samping itu, peneliti juga mengumpulkan dan menganalisis data serta sebagai pelapor hasil penelitian.

Dalam pelaksanaan penelitian tindakan kelas ini yang menjadi subjek penelitian adalah peserta didik di kelas V SDS Muhammadiyah Plus yang berjumlah 10 orang. Terdiri dari 5 peserta didik perempuan dan 5 peserta didik laki-laki. Sedangkan yang menjadi objek penelitian adalah hasil belajar IPA.

Pengumpulan data yang diperoleh pada penelitian ini dilakukan melalui pengamatan (observasi) dan tes hasil belajar.

Data yang dikumpulkan dari setiap kegiatan yang dilaksanakan dalam siklus PTK dianalisis secara deskriptif dengan menggunakan teknik persentase untuk melihat kecenderungan yang terjadi dalam pembelajaran. Data yang diperoleh melalui instrumen yang telah 
dikumpulkan sebelumnya diolah menjadi dua jenis data yaitu kuantitatif dan kualitatif.

Data kuantitatif berasal dari hasil tes yang diberikan pada setiap akhir siklus kegiatan. Hal ini dilakukan untuk mengetahui peningkatan hasil belajar peserta didik pada pendekatan yang diterapkan

Data kualitatif diperoleh dari aktivitas terhadap peneliti dan aktivitas terhadap peserta didik dan respon peserta didik selama proses belajar rmengajar dengan menganalisis hasil belajar yang dilihat dalam proses belajar mengajar menggunakan pendekatan saintifik.

\section{HASIL DAN PEMBAHASAN}

Data dari hasil penelitian ini berupa : 1) pengamatan aktivitas guru dan peserta didik 2) hasil belajar IPA menggunakan pendekatan saintifik

1) Pengamatan aktivitas guru dan peserta didik

Aktivitas guru dan peserta didik dapat dilihat pada tabel dan gambar berikut :

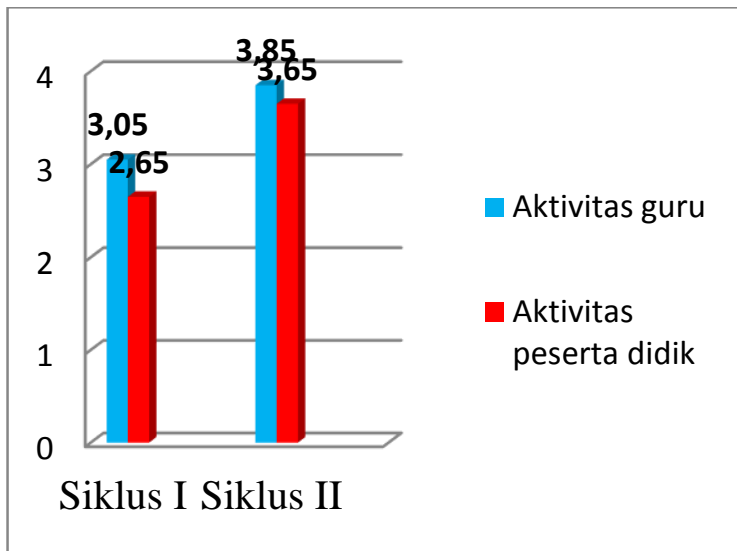

\section{Gambar 1}

Diagram Rekapitulasi Data Observasi Aktivitas Guru dan Peserta Didikpada Siklus I dan Siklus II
Berdasarkan tabel dan diagram diatas, melalui perbaikan pembelajaran dengan menggunakan pendekatan saintifik pada materi perubahan sifat benda yang dilaksanakan oleh peneliti di kelas V SDS Muhammadiyah Plus aktivitas guru dan peserta didik menunjukkan perkembangan yang baik. Aktivitas guru dan peserta didik pada siklus I oleh pengamat I memperoleh nilai rata-rata 3 untuk aktivitas guru dan 2,6 untuk aktivitas peserta didik, dan pengamat 2 memperoleh nilai ratarata 3,1 untuk aktivitas guru dan 2,7 untuk aktivitas peserta didik. Sedangkan pada siklus II ada peningkatan yang sangat baik, dengan penilaian oleh pengamat 1 memperoleh nilai rata-rata 3,8 untuk aktivitas guru dan 3,6 untuk aktivitas peserta didik, dan pengamat 2 memperoleh nilai rata-rata 3,9 untuk aktivitas guru dan 3,7 untuk aktivitas peserta didik. Berdasarkan hasil tersebut dapat dilihat bahwa terjadi peningkatan aktivitas guru dan peserta didik dari siklus I ke siklus II.

2) Hasil belajar IPA peserta didik menggunakan pendekatan saintifik

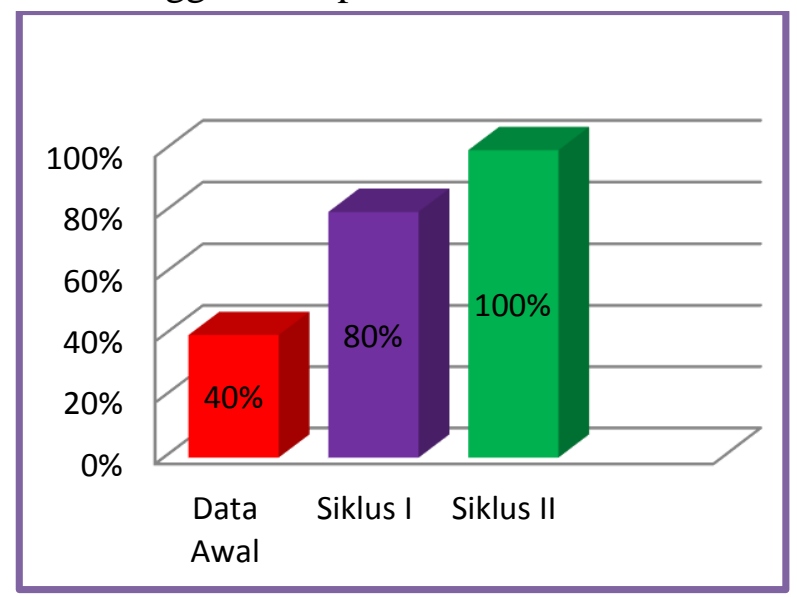

Gambar 1

Diagram Rekapitulasi siklus I dan siklus

II 
Berdasarkan tabel dan diagram diatas, hasil data awal, siklus I dan siklus II terlihat adanya peningkatan hasil belajar pada pelajaran IPA pada materi perubahan sifat benda dengan menggunakan pendekatan saintifik terhadap peserta didik kelas V di SDS Muhammadiyah Plus . Dapat dilihat bahwa pada data awal peserta didik hanya memperoleh nilai rata-rata 52 , nilai ini masih jauh dari kriteria ketuntasan yaitu 60. Hasil ketuntasan belajar peserta didik pun hanya memperoleh nilai sebesar $40 \%$. Nilai ini sangat jauh dari kriteria ketuntasan klasikal dimana nilai yang ditentukan yaitu $85 \%$. Kemudian pada siklus I nilai rata-rata peserta didik meningkat menjadi 71, nilai ini sudah mencapai kriteria ketuntasan minimum yang ditentukan. Hasil ketuntasan klasikal belajar peserta didik pun meningkat yakni memperoleh nilai $80 \%$ nilai ini hampir mencapai kriteria ketuntasan klasikal yang ditentukan. Sehingga harus mengoptimalkan lagi proses pembelajaran pada siklus II yang mana pada siklus II memperoleh nilai ratarata 83,5 nilai ini mengalami peningkatan dari tindakan sebelumnya dan ketuntasan klasikalnya menjadi $100 \%$.

\section{SIMPULAN}

Berdasarkan hasil penelitian yang telah dibahas maka dapat disimpulkan:
1. Aktivitas belajar peserta didik kelas V SDS Muhammadiyah Plus pada pembelajaran IPA dengan menggunakan pendekatan saintifik meningkat, menjadi lebih bersemangat dan aktif.

2. Ada peningkatan hasil belajar IPA dengan menggunakan pendekatan saintifik pada peserta didik kelas $\mathrm{V}$ SDS Muhammadiyah Plus Kabupaten Kapuas Tahun Pelajaran 2014/2015. Peningkatan tersebut dapat dilihat dari hasil belajar peserta didik pada mata pelajaran IPA khususnya pada materi perubahan sifat benda. Pada siklus I perolehan nilai rata-rata peserta didik yaitu 71 dengan ketuntasan klasikal $80 \%$ dan mengalami peningkatan pada siklus II dengan rata-rata nilai 83,5 dan ketuntasan klasikal $100 \%$.

\section{DAFTAR PUSTAKA}

Daryanto. (2014). Pendekatan Pembelajaran Saintifik.

Yogyakarta: Gava Media

Kunandar. (2012). Langkah Mudah Penelitian Tindakan Kelas.

Jakarta: PT

RajaGrafindo Persada.

Wahyudin,Din.,dkk. (2008). Pengantar Pendidikan. Jakarta: Universitas Terbuka. 